\title{
Determinant Factors of Taxpayer Satisfaction in Using the Electronic Tax Invoice Number (E-NOFA) in the Emerging Technology Era
}

\author{
Mirza Maulinarhadi*, Latifah Hanum, Arina Hana Mahardika \\ Department of Taxation Program \\ Brawijaya University \\ Malang, Indonesia \\ *mirza_mr.fia@ub.ac.id
}

\begin{abstract}
Tax is an important role in a country. State revenue from the taxation sector is a source of income based on the type of collection, one of which is the central tax. Central Tax is a tax collected by the central government, consists of Income Tax (IT), Value Added Tax (VAT) and others. One of the state revenues in Indonesia depends on collecting VAT. VAT has two types of administrative procedure, namely input tax and output tax. In the payment of VAT, the taxable entrepreneur can credit the input tax paid with the output tax collected within the same tax period. This phenomenon is in line with the use of fictitious invoices numbering on the handover of taxable services or taxable goods made by entrepreneurs who carry out value added tax refunds. Therefore, the application of electronic tax invoice number (E-Nofa) is expected to be able to prevent the use of fictitious tax invoices and facilitate the supervision of tax invoice numbering system used by taxble entrepreneurs. This type of research used is explanatory research with a quantitative approach. Variables used are system quality, information quality, service quality and perceived usefulness as the independent variable, and taxpayer satisfaction as dependen variable. The research purpose is to test and analyze the effect of system quality, information quality, service quality and perceived usefulness on taxpayer satisfaction in the use of electronic tax invoice number (E-Nofa). The results showed that the service quality and perceived usefulness significantly affects to taxpayer satisfaction. While the system quality and information quality are not has a significant effect on taxpayer satisfaction. The conclusion of this study is that the taxpayer satisfaction of use of electronic tax invoice number (E-Nofa) in the Northern Malang tax office area affect with the service quality and perceived usefulness on the electronic tax invoice number (E-Nofa).
\end{abstract}

Keywords-taxpayer satisfaction, electronic tax invoice number, e-nofa

\section{INTRODUCTION}

The tax has an essential role in a country. According to reference Djajadiningrat [1], the tax is an obligation to give part of the taxpayer's wealth to the state treasury due to a particular situation. The government determines the tax, and it can be imposed without providing reciprocal services directly. State revenue from the taxation sector is the most crucial source of income, of which the primary use is to maintain general welfare. State revenue obtained from the taxation sector is based on the type of collection, one of which is the central tax. In that case the Value-added tax (VAT) is one of the central taxes.

The VAT is collected using a holding system: third parties administer tax obligations. Taxable entrepreneurs are people (or institutions) that should administer the VAT. They can apply the input-tax-credit system on the output tax collected, proved by a valid tax invoice. According to this, the tax invoice has a vital role in administering the VAT [2]. Based on the Regulation of the Directorate-General of Taxes No. 24 of 2012 concerning invoices, a tax invoice is evidence of tax collection made by a taxable entrepreneur overhand taxable goods or providing taxable services. In Indonesia, this provision is currently misused by certain parties, such as using a fictitious tax invoice to deliver Taxable Services or Taxable Goods.

A fictitious tax invoice is a tax invoice issued by an individual or entrepreneur unconfirmed as a Taxable Entrepreneur, or a tax invoice based on fictitious transactions. The issuance of this fictitious tax invoice can lead to the reduction of VAT. As seen in Table 1.1 below, in 2015-2018, the VAT were varied. They tended to increase because of tax reforms in VAT: automatic numbering arrangements were implemented for tax invoices issued by taxable entrepreneurs. The Directorate-General of Taxes has implemented Electronic Invoice Number (E-Nofa) since 2014 in general. However, in practice it can be adjusted to the readiness of the tax office in each region. That's role is expected to prevent the use of fictitious tax invoices and facilitate tax invoice numbering from taxable entrepreneurs. Following tax reform in terms of information system development, taxpayers must adapt to existing developments.

Likewise in industrial development 4.0, Indonesian people are required to follow the rapid development of the use of technology and information. The impact of the 4.0 industrial 
revolution era brings a big shock to the industrial world and behavior in society. Everything has been rapidly digitalized. The interaction between humans and technology is inevitable. All human needs can now be fulfilled digitally, like buying or selling stuff and services, paying bills. On the other hand, the Covid-19 Pandemic has triggered an increase in digital media use in various parts of the world and Indonesia, caused by the government role to spend more time at home to reduce virus transmission. The pandemic has spurred entrepreneurs to better adapt to digital or online media in running their businesses. The pandemic has caused new technologies to emerge and be used by the community to support their daily needs.

TABle I. National Value-AdDed Tax (VAT) ReVEnUe Data (IN MILLION IDR)

\begin{tabular}{|c|c|l|l|}
\hline Year & Target & \multicolumn{1}{|c|}{ Realization } & \multicolumn{1}{|c|}{ Realization (\%) } \\
\hline 2015 & 557,421 & 410,334 & 73.61 \\
\hline 2016 & 456,361 & 396,034 & 86.78 \\
\hline 2017 & 455,325 & 463,536 & 101.80 \\
\hline 2018 & 541,800 & 538,200 & 99.34 \\
\hline
\end{tabular}

Source: Data processed in 2018

Electronic Invoice Number (E-Nofa) is a form of service provided by the Directorate-General of Taxes to taxpayers, especially taxable entrepreneurs. It is carried out through controlled tax invoice serial numbers issued by the DirectorateGeneral of Taxes [3]. Taxpayers used to take invoice-numbers freely, but now it is no longer allowed. E-Nofa aims to match data easier by producing more valid data than manual numbering; thus, control over output tax data and input taxes can be improved. It can prevent data changes by people by restricting data access. Therefore, E-Nofa is expected to increase VAT revenue.

E-Nofa is an improved information system in the tax reform. The success of the information system application is measurable and can be seen from the taxpayers' level of satisfaction as its users. The level of satisfaction is used to determine whether the system accommodates users' expectations. An information system is successful if the system's quality is good, and the good-quality information generated from the system is supported by exemplary service from the information system provider. Based on these circumstances, the researchers were interested in examining taxpayer satisfaction with the E-Nofa system. The problem statement are (1) Does the quality of the E-Nofa system effect on taxpayer satisfaction, 2) Does the quality of information generated from E-Nofa effect on taxpayer satisfaction, 3) Does the quality of E-Nofa service effect on taxpayer satisfaction, and 4) Does the perceived usefulness of E-Nofa effect on taxpayer satisfaction.

\section{RELATED WORKS}

\section{A. Previous Research}

Research conducted by Negash et al. [4] aimed to determine the quality and effectiveness of a web-based customer support system in Greece. This research indicated that information and system quality determined effectiveness, but service quality did not. The current study is different in 'effectiveness' as a variable, and similar in the system quality, information quality, and service quality variables.

Research conducted by Baridwan aimed to determine the quality and effectiveness affecting user satisfaction; the research was conducted to computer-based information system users in Malang city and indicated that service quality provided an immense contribution, compared to information and system quality [5]. Regarding the current study, the object was different, but the variables were the same: system quality, information quality, and service quality.

Research conducted by Wang and Liao aimed to assess the E-Government system's user satisfaction in Jordan [6]. The research revealed that the variables and the perceived net benefits were valid measures of the E-Government system's success. All hypothetical relationships of the six success variables were significant except for the effect of system quality on usage. The current study had a different research object, but similar variables: system quality, information quality, service quality, usage, and user satisfaction.

Research conducted by Floropoulus et al. [7] aimed at measuring the success of the Greek taxation information system and indicated a strong relationship between the variables used (information quality, system quality, service quality, and perceived usefulness in user satisfaction). However, the current study was conducted in a different country with the same variables: system and information quality.

Research conducted by Rukmiyanti [8] aimed to empirically prove the effect of information system quality, information quality, and perceived usefulness on an accounting software's end-user satisfaction. The results showed that the better the quality of information systems, information quality, and perceived usefulness, the better the end-users satisfaction. The current study had a different research object but the same variables.

\section{B. References}

1) DeLone and McLean's information system success model: The best-known success and validity-test model is proposed by DeLone and McLean [9]. Reference DeLone and McLean [9] proposed six categories in the information system success model: system quality and competence to use, information quality, usability, user satisfaction, individual performance, and organizational performance. In its development, the role of information systems went through many changes. During the ten years since the information system success model DeLone and McLean [9] was first introduced, improvements were made. In 2003, DeLone and McLean developed a model by exploring several variables in a new system success model. As an indicator of intention to use, the perceived-usefulness variable played an essential role in the success of information and contributed to the development 
of information system technology. Figure 1 presents DeLone and McLean's model of information-system success development [10].

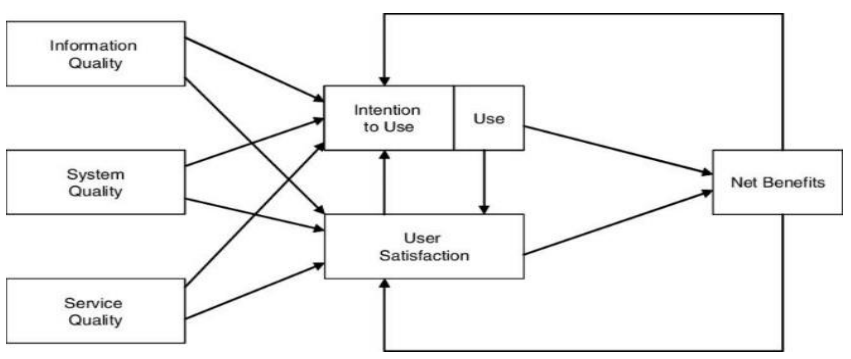

Fig. 1. DeLone and McLean's Model of Information System Success, Source: DeLone and McLean [10].

According to reference DeLone and McLean [10], user satisfaction can be seen from three dimensions: system quality, information quality, and service quality; it can replace use with intention-to-use. The success of a system is measured based on the user's satisfaction. A quality system will produce quality information; thus, it can provide satisfaction for its users. Good service quality will also affect user satisfaction.

2) Usability perception: Perception is a process by which a person chooses, accepts, organizes, and interprets the information he receives from the environment [11]. Perception is how individuals organize and interpret their sensory impressions to give meaning to their environment [12]. Thus, it can be argued that perception is a person's process of selecting, receiving, interpreting information to be disclosed to the surrounding environment. In other words, it is a person's level of understanding when viewing information according to that person's perspective. Technology Acceptance Model is a model for information-technology system acceptance used by users. According to reference Davis et al., in Jogiyanto , developed the technology acceptance model (TAM), based on the TRA (Theory of Reasoned Action) model.

3) Electronic tax invoice number (E-Nofa): The application for requsting electronic tax invoice serial number (E-Nofa) to value-added tax is a form of tax modernization carried out by the Directorate-General of Taxes. Based on reference the regulations of the Directorate General of Taxes No. 24/PJ/2012 [14], a tax invoice serial number is given by the Directorate-General of Taxes to a Taxable Entrepreneur with a specific mechanism for numberings, such as numbers, letters, or a combination of numbers and letters. Each tax invoice must use a code given by the Head of the tax-Service office to a taxpayer confirmed as a Taxable Entrepreneur. Therefore, the Taxable Entrepreneur must notify the Head of the tax-service office, where he is appointed to obtain a tax invoice code. Taxable Entrepreneurs cannot use the tax invoice code arbitrarily as the tax office controls it. With the launch of a new and reliable system of an electronic taxinvoice serial number system (E-Nofa), it is expected that matching data is easier and more valid than manual numbering. Besides, controlling tax invoice numbering is now easier to effectively prevent a fictitious tax invoice.

\section{Methodology}

\section{A. Type of Research}

This is explanative research using a quantitative approach to examine the effect of system quality, information quality, service quality, and perceived usefulness on taxpayer satisfaction when using an electronic tax invoice number (ENofa). The population of this research is taxpayers who used ENofa at Pratama tax offices in Malang, which were 1204 taxpayers. The samples was calculated base on the Slovin formula as many as 92 tax payers dan taken randomly. The data were collected using the survey method, with an online questionnaire.

\section{B. Data Analysis Method}

The multiple regression method was used for analyzing the data and examining the hypothesis in this research. It was necessary to test the model's feasibility before the hypothesis test; this research used the t-test analysis. The F test was used to test the regression model's significance or insignificance. A partial significance examination or T-test showed how far the effect of one independent variable could partially explain the variation of the independent variables [15]

\section{RESULTS AND DISCUSSION}

\section{A. Model Fit Test: To See the Results of the Coefficient of}

Determination $\left(R^{2}\right)$

The results of the coefficient of determination $\left(R^{2}\right)$ is presented in Table 2 :

TABLE II. DETERMINATION COEFFICIENT TEST

\begin{tabular}{|l|l|l|l|l|}
\hline Model & \multicolumn{1}{|c|}{ R } & R Square & $\begin{array}{c}\text { Adjusted R } \\
\text { Square }\end{array}$ & $\begin{array}{l}\text { Std. Error of } \\
\text { the Estimate }\end{array}$ \\
\hline 1 & $0.856^{\mathrm{a}}$ & 0.732 & 0.707 & 0.676 \\
\hline
\end{tabular}

As seen in Table 2, the R-Square value is 0.732 , this shows that the effect of system quality (X1), information quality (X2), service quality (X3), and perceived usefulness (X4) on satisfaction $(\mathrm{Y})$ is $73.2 \%$. It means that the effect's proportion of system quality (X1), information quality (X2), service quality (X3), and perceived usefulness (X4) on satisfaction (Y) is $73.2 \%$. The remaining $26.08 \%$ belong to other variables outside the linear regression model. 


\section{B. F Test Results}

A simultaneous significance test was conducted to determine whether all independent variables simultaneously significantly affect the dependent variable. Based on the calculation, the significance value of $0.000<0.05$ seen on table 3 , so $\mathrm{Ha}$ is accepted. And the calculated $\mathrm{F}$ value is higher than the F table; as 28.7 is higher than 2.6. It means that the regression model parameters are fit or acceptable.

TABLE III. F TEST RESULTS

\begin{tabular}{|c|c|c|}
\hline F & F table & Sig. \\
\hline 28,689 & 2.59 & 0.000 \\
\hline
\end{tabular}

Source: Data Processed by Researchers, 2020

\section{The Results of Multiple Linear Regression Analysis Test}

Multiple linear regression analysis is used to test the independent variable's effect on the dependent variable. The independent variables are System Quality (X1), Information Quality (X2), Service Quality (X3), Perceived Usability (X4). The dependent variable is Taxpayer Satisfaction in using the Electronic Tax Invoice Number (E-Nofa) System (Y).

TABLE IV. REGRESSION EQUATIONS

\begin{tabular}{|l|l|l|}
\hline \multirow{2}{*}{ Variable } & \multicolumn{2}{c|}{ Unstandardized Coefficient } \\
\cline { 2 - 3 } & \multicolumn{1}{|c|}{$\boldsymbol{B}$} & Std. Error \\
\hline (Constant) & -.637 & 1.666 \\
\hline System quality & .058 & .037 \\
\hline Information quality & -.066 & .058 \\
\hline Service quality & .157 & .062 \\
\hline Perceived usability & .806 & .180 \\
\hline \multicolumn{2}{|c|}{ Source: Data Processed by Researchers, 2020}
\end{tabular}

The multiple linear regression equation obtained based on Table 4 is as follows:

$$
\begin{aligned}
& Y=a+b_{1} X_{1}+b_{2} X_{2}+b_{3} X_{3}+b_{4} X_{4}+e \\
& Y=0,637-0,058 X_{1}+0,66 X_{2}-0,157 X_{3}-0,806 X_{4}
\end{aligned}
$$

\section{T Test Results}

A partial significance test is used to determine whether each independent variable partially has a significant effect on the dependent variable. If the value is prob. $t$ count (SPSS output shown in column sig.) is lower than the predetermined error rate (alpha), it can be said that the independent variable (from the $t$ count) has a significant effect on the dependent variable. In contrast, if the value is prob. $t$ count is higher than the predetermined error rate (alpha), it can be said that the independent variable has no significant effect on the dependent variable. The regression model testing in this study can be seen in Table 5:
TABLE V. PARTIAL TEST RESUlts

\begin{tabular}{|l|l|l|l|l|}
\hline Var & \multicolumn{1}{|c|}{ t } & \multicolumn{1}{c|}{ T table } & \multicolumn{1}{c|}{ Sig. } & \multicolumn{1}{c|}{ Result } \\
\hline $\mathrm{X} 1$ & 1,570 & 1.678 & 0.124 & Rejected \\
\hline $\mathrm{X} 2$ & $-1,130$ & 1.678 & 0.265 & Rejected \\
\hline $\mathrm{X} 3$ & 2,512 & 1.678 & 0.016 & Accepted \\
\hline $\mathrm{X} 4$ & 4,478 & 1.678 & 0.000 & Accepted \\
\hline
\end{tabular}

\section{E. Discussion and Interpretation}

The research aim are to testing and analyzing 1) the effect system quality of E-Nofa on taxpayer satisfaction, 2) the effect quality of information generated from E-Nofa on taxpayer satisfaction, 3) the effect service quality of E-Nofa on taxpayer satisfaction, and 4) the effect perceived usefulness of E-Nofa on taxpayer satisfaction. This is a discussion of the test result for each research aim:

- The results of testing the first hypothesis for the first research aim show that the sig. value for the effect of $\mathrm{X} 1$ on $\mathrm{Y}$ is 0.124 , which is higher than the sig. value of 0.1 so that the system quality variable (X1) does not significantly affect Taxpayer Satisfaction (Y). This study's results are not in line with the theory of DeLone and McLean [10], which explains that system quality affects user satisfaction. However, it follows the results of research conducted by Negash et al. [4], Floropoulus et al. [7], and Rukmiyanti [8], revealing that system quality does not affect taxpayer satisfaction. According to DeLone and Mclean [9], system quality is a characteristic of information inherent about the system itself. The quality of the system in this study discusses the characteristics of the information system used, such as system flexibility, system reliability, ease of learning, and system use. The system quality measure determines the level of user satisfaction. If the quality of the system runs well, users tend to be satisfied with the use of the system. Several things that cause the system quality in this research are not significant to taxpayer satisfaction: 1) The use of E-Nofa by taxable entrepreneurs is still in a recent periode so that the flexibility of the system and its reliability cannot be significantly felt. This is because using E-Nofa requires additional procedures that must be performed by taxable entrepreneurs in managing the administration of obtaining tax invoice numbers electronically, this can affect the ease of learning and using the system for users. 2) Related to the validity period of the electronic invoice number, where its use has a time limit that requires routine procedures to extend the period of use, this is quite difficult for some users so that it cannot be said to have flexibility in the system. 3) The operation of E-Nofa has not been carried out optimally by taxable entrepreneurs, so that the reliability of the information generated is only beneficial for some taxable businessmen who have used it and their stakeholders, so they cannot describe the quality of E-Nofa as a whole.

- The results of testing the second hypothesis for the second research aim show that the sig. value for the 
effect of $\mathrm{X} 2$ on $\mathrm{Y}$ is 0.265 , which is higher than the sig. value of 0.1 , so the information quality variable (X2) does not significantly affect the Taxpayer Satisfaction variable (Y). This study's results are not in line with the theory of DeLone and McLean [10], which explains that information quality affects user satisfaction. However, the results of this study are in line with the results of research conducted by Wang [6], Floropoulus et al. [7], Rukimyanti [8], asserting that information quality has no significant effect on user satisfaction. Based on Negash, et al. [4], define the quality of information as a function of the output value produced by a system as perceived by users. Good quality information affects the decisions that will be taken. The better quality of information will affect the level of user satisfaction. And poor information quality will harm user satisfaction. Good quality information will affect the level of user satisfaction. One of the reasons for the insignificant variable quality of information on taxpayer satisfaction is due to the lack of socialization regarding the electronic invoice numbering period limit rules that will expire so that when the certificate expires, taxable entrepreneurs have to delay their business transactions because they have to request a new electronic invoice number. This requires additional procedures to be performed and to take time. In addition, system users are still in the adaptation stage of using E-Nofa as a new system, so that the reliability of the information generated cannot be used optimally in their business processes.

- The results of testing the third hypothesis for the third research aim show that the sig. value for the effect of $\mathrm{X} 3$ on $\mathrm{Y}$ is 0.016 , which is lower than the sig. value of 0.05 , so the service quality variable $(\mathrm{X} 3)$ significantly affects Taxpayer Satisfaction (Y) with a confidence level of $95 \%$. This study's results are in line with the theory of DeLone and McLean [10], which explains that service quality affects user satisfaction. This study's results are in line with the research results conducted by Negash et al. [4], showing that service quality had no significant effect on user satisfaction. Entrepreneurs who are taxed as corporate taxpayers in Malang city experience the good-service quality. It is different from the research results conducted by Baridwan [5], Floropoulus et al. [7], stating that the service quality variable did not significantly affect user satisfaction. According to DeLone and McLean [10], service quality can be realized if customer needs, and expectations are met. The service quality in this study discusses the quality of service received by users from the system used, such as responsiveness, accuracy, and reliability of services. The service quality is measured by the part being served based on expectations in fulfilling their satisfaction. Good quality service will provide satisfaction to taxable entrepreneurs
- The results of testing the fourth hypothesis for the fourth research aim reveal that the sig. value for the effect of $\mathrm{X} 4$ on $\mathrm{Y}$ is 0.000 , which is lower than 0.01 ; so, the perceived usefulness variable (X4) significantly affects user satisfaction (Y) with an accurate level of $99 \%$. This study's results are in line with the Technology Acceptance Model (TAM) and research conducted by Floropoulus et al. [7], Rukmiyanti [8], showing that the usability perception variable significantly affects user satisfaction. TAM is a model in measuring the acceptance of information technology systems used by users; based on TAM, a person's acceptance of information technology is determined by two primary constructs: perceived usefulness and perceived ease-of-use. The Technology Acceptance Model claims that if a technology or innovation maximizes a person's performance and does not affect one's efforts to perform a function, it is useful and easy to use. Individuals will be more likely to adopt the technology, service, or action.

\section{CONCLUSION AND SUGgESTION}

This study's results indicated that the quality of the E-Nofa system and the quality of the information did not significantly affect taxpayer satisfaction. The respondents considered the ENofa a relatively new system; this could affect their opinions in assessing the system and information quality based on the limited experience of using the system, which was less than one year. Service quality and the perceived usefulness significantly affected taxpayer satisfaction in using the E-Nova system. Good service quality can be achieved when customer needs and expectations are met. So, it can be said that the good quality of service provided by the Directorate-General of Taxes satisfied the taxpayers who use the E-Nova system. Meanwhile according to Technology Acceptance Model, if a technology or innovation (E-Nofa) can maximize one's performance and does not affect one's efforts to perform a function, it is useful and easy to use; thus, people prefer to adopt that technology, service, or action.

Following the conclusion, the researcher has some suggestions expected to be useful for concerned parties: 1) It is hoped that there will be clear counseling and socialization regarding the obligation to use the E-Nofa system, its benefits, convenience, and the validity period for using automatic invoice numbers to avoid expiration, 2) there should be a proper guide or tutorial on using the E-Nova system distributed through social media, and 3) the Directorate-General of Taxes should anticipate system failures and user data security problems with a strong security system.

\section{REFERENCES}

[1] S.I. Djajadiningrat, Asas dan Dasar perpajakan 2. Bandung. Eresco, 1965.

[2] N. Atikasari, Analisis Penerapan Faktur Pajak Elektronik Sebagai Upaya Mencegah Penerbitan Faktur Pajak Fiktif (Studi pada Kantor Pelayanan 
Pajak Pratama Surabaya Gubeng). Fakultas Ilmu Administrasi Bisnis Universitas Brawijaya Malang

[3] Anonim. Elektronik Nomor Faktur. www.online-pajak.com. Diakses tanggal 30 September 2019.

[4] S. Negash, T. Ryan and M. Igbaria, "Quality and Effectiveness in Webbased Costomer Support System," Journal of Information and Management, vol. 40, pp. 757-768, 2003.

[5] B. Badriawan and H. Hanum, "Kualitas dan Efektivitas Sistem Informasi Berbasis Komputer," 2017.

[6] Y.S. Wang, and Y.W. Liao, "The Conceptualization and Measurement of M- commerce User Satisfaction," Computers in Human Behavior, vol. 23, no. 1, pp. 381-398, 2007.

[7] J. Floropoulus, C. Spathis, D. Halvatzis and M. Tsipouridou, "Measuring the success of the Grek TaJournal of Inforxation Information System," mation Management, no. 30, pp. 47-56, 2010.

[8] N.M.S. Rukmiyati, and I Ketut Budiartha, "Pengaruh Kualitas Sistem Informasi, Kualitas Informasi dan Perceived Usefullness Pada Kepuasan Pengguna Akhir Software Akuntansi (Studi Empiris Pada Hotel Berbintang di Provinsi Bali). Bali : Universitas Udayana,” E-Journal
Ekonomi dan Bisnis Universitas Udayana. ISSN : 2580-5312. vol. 5 no.1, pp. 122, 2016.

[9] W.H. DeLone and E.R. McLean, "Information Systems Success: The Quest for the Dependent Variable," Inf. Syst. Res., vol. 3, no. 4,:60-95, 1992.

[10] W. DeLone and E.R. McLean, "The DeLone and McLean Model of Information System Success: A Ten Year Update.," Journal of Management Information Systems, 2003.

[11] S. Herlan and B. Yono, Psikologi Pelayanan. Bandung: Penerbit Media Perubahan, 2013.

[12] S. Robbins, Perilaku Organisasi, Jilid I dan II, alih Bahasa : Hadyana Pujaatmaja. Jakarta: Prenhallindo, 2008.

[13] Jogiyanto, Sistem Informasi Keperilakuan. Yogyakarta: Andi, 2007.

[14] Peraturan Dirktur Jendral Pajak Nomor PER-24/PJ/2012 tentang Bentuk, Ukuran, Tata Cara Pengisian Keterangan, Prosedur Pemberitauan Dalam Rangka Pembuatan, Tata Cara Pembetulan atau Penggantian, Dan Tata Cara Pembatalan Faktur Pajak.

[15] I. Ghozali, Aplikasi Analisis Multivariate dengan Program IBM SPSS 23. Semarang: Badan Penerbit Universitas Diponegoro, 2016. 